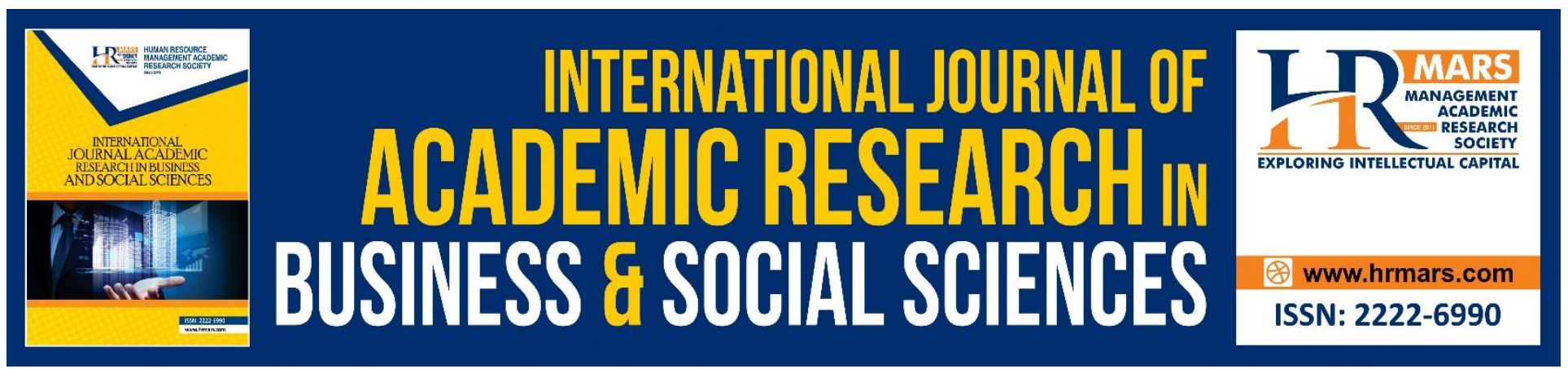

\title{
The Impact on Businesses and Public Health Using Lock Down as a Tool against Covid-19 Pandemic in Italy: A Global Perspective
}

\section{Ubaldo Comite}

To Link this Article: http://dx.doi.org/10.6007/IJARBSS/v10-i5/7210

DOI:10.6007/IJARBSS/v10-i5/7210

Received: 10 March 2020, Revised: 12 April 2020, Accepted: 28 April 2020

Published Online: 17 May 2020

In-Text Citation: (Comite, 2020)

To Cite this Article: Comite, U. (2020). The Impact on Businesses and Public Health Using Lock Down as a Tool against Covid-19 Pandemic in Italy: A Global Perspective. International Journal of Academic Research in Business and Social Sciences, 10(5), 394-405.

Copyright: (C) 2020 The Author(s)

Published by Human Resource Management Academic Research Society (www.hrmars.com)

This article is published under the Creative Commons Attribution (CC BY 4.0) license. Anyone may reproduce, distribute, translate and create derivative works of this article (for both commercial and non-commercial purposes), subject to full attribution to the original publication and authors. The full terms of this license may be seen

at: http://creativecommons.org/licences/by/4.0/legalcode

\section{Vol. 10, No. 5, 2020, Pg. 394 - 405}

Full Terms \& Conditions of access and use can be found at http://hrmars.com/index.php/pages/detail/publication-ethics 


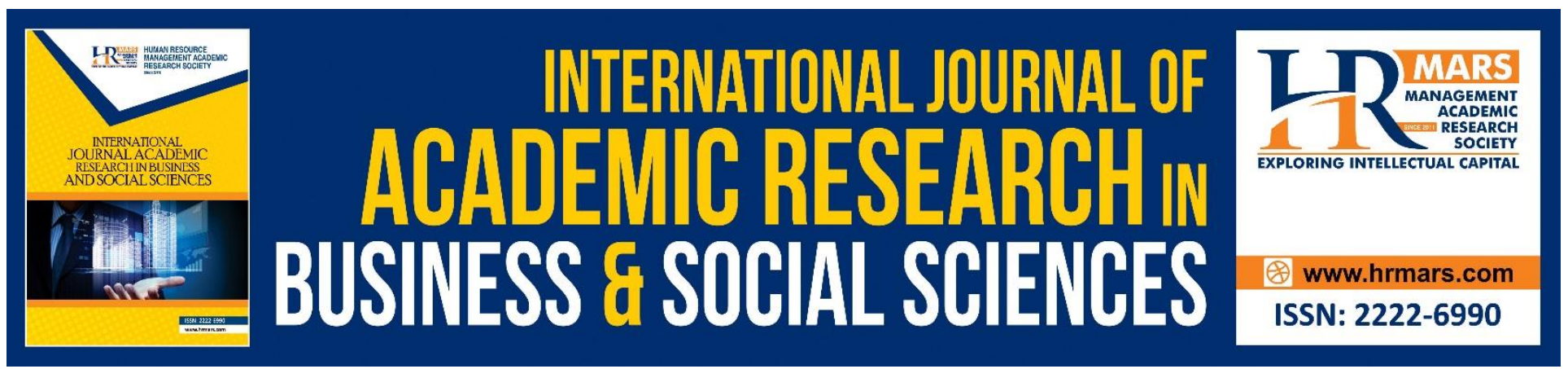

\title{
The Impact on Businesses and Public Health Using Lock Down as a Tool against Covid-19 Pandemic in Italy: A Global Perspective
}

\author{
Ubaldo Comite \\ University "Giustino Fortunato", Benevento, Italy
}

\begin{abstract}
Since the spread of Corona Virus Disease 19 (COVID -19) most Italian regions on indication of the Central Government have embarked on a system of either total or partial lock down and have used it as a tool for curbing the spread of COVID-19. This study examines whether lock down can be of help and is it any of the public health policies and can it bring up massive and tremendous change to the health system and general economy to Italian regions that have used it as a way of intervention in the spread of COVID19.
\end{abstract}

The research reviewed some literatures about word economies with Google as the main search tool. Have been also listened to press conferences, editorial reviews from Italian newspapers, Bank of Italy, World Bank, International Monetary Fund and World Health Organization. Interviews were also done through phone calls, questions asked via emails to some of the italian leading epidemiologist, infectious disease specialist in the Italy, carefully reading their scientific works and those scientists they cited. Also, the research individual experience and observations on the COVID-19 pandemic in Italy and measures that policy makers have laid down to mitigate the global health crisis of COVID19 and its effect in the general economy.

After a careful study and analysis of various countries (Germany, Spain, France, Italy) that embarked on lock down either partial or complete is showing plummeting inflation, declining gross domestic product, loss of capital for business groups, loss of jobs especially in the informal sectors, a negative growth due to disruption of the world economy through global value chains, abrupt fall in commodity prices and fiscal revenues and enforcement of travel and social restrictions.

The research found that a national lock down is no cure, has never been a cure and is not a cure to any of the pandemics be it previous or recent either in the history of the Spanish flu, influenza and the pending COVID-19.

Lock down is only an intervention to prevent exponential spread of the pandemic. Although an intervention, it can lead to a mishap and worse scenario so far as health economy and both micro and macroeconomic indicators are concerned. 
The research also found that lock down seem to be of a politically enforced measure than a public health policy and should not be the main weapon by Italian governments to fight the COVID-19 pandemic. As demonstrated and proven by the Asian giants (Japan, Hong Kong, Singapore, South Korea, Taiwan) who never embarked on draconian lock down methods and intensive restriction orders (Gordis, 2017; Edgerg, 2017).

The research shows that is time public health systems of Italian regions are strengthened with befitting budgets, human resource developments, more public health educators recruited to use the mass media be it local radio stations television stations, internet to educate the populace on the effects of pandemics on the country, precaution, preventions and safety steps to follow.

The research saw the need and have seen the need as an urgent call for Italian political leaders to put in much effort and develop science and technology especially in the field of health and biomedical sciences. More research laboratories with modern equipments and instruments should be set up in many regions of country coupled with the continuous need and sponsorships to train many research scientists in the fields of biomedical science, biomedical engineering, biotechnology, molecular medicine and biochemistry, Laboratory medicine, public health and epidemiology, infectious disease etc and such can be a solid ground for Italy to stand on whenever there is an outbreak of diseases.

Furthermore the M3T that is mass testing, tracing and treating should be a must in this pandemic era and even when figures flatten until total control or herd immunity is gained and acquired. In the M3T, M stands for mass, 1st T for testing, 2nd T for tracing and last T for treating or treatment.

In addition, the research also shows that the 2SQ that is social distancing, self isolation and quarantine is an indispensible tool in this pandemic season and should be enforced to the core to help in the management of COVID-19. In the $2 S Q$, the $2 S$ stand for social distancing and self isolation while the $Q$ stands for quarantine.

Keywords: COVID-19, Pandemic, Lock Down, M3T, 2SQ, Businesses, Italy, Europe.

\section{Introduction}

The purpose of lockdown is intended to stop people from moving between places, it could also mean putting data in place to record the movement of people from place to place in a particular location. Lock downs could involve cancelling of flights both domestic and international, closing borders, closing down shops, restaurants, schools, churches etc with the main idea by governments to reduce the influx of people to stop transmission of a disease.

Almost all the World countries are inadequately prepared to deal with the exponential spread of COVID-19 with its pseudo recovery and recovery features and Italy is no exception coupled with weak health systems, scanty resources, economic and spatial inadequacies on lock down and massive restriction orders from government and it seems to most Italian regions lock down is a major tool and intervention to stop COVID-19.

\section{Basic Epidemiology Trend}

The number of COVID-19 cases in Italy has quickly risen to more than 200.000 and the death rate exceeds 27.000 (to april 30th, 2020) and this can be termed as above global average (except to USA). This steady increasing high death rate of the Italy but with less number of confirmed cases should tell us that Italy rather is doing very low rate of COVID-19 testing and this can be fatal and deadly if proper public health interventions are not put in place and to get the best practices of public health 
interventions a country needs the capital or income, trained public health personnel, infrastructure as in treatment centers and isolation centers, special hospitals for such purpose with equipments and tools. The World Health Organization says the Italy has 6.1 nurses and midwives for every 1000 inhabitants and 3.8 doctors for every 1000 inhabitants. This really shows how is porous and weak our health system. Since the spread many World countries have put in measures to help respond quickly to the pandemic and despite all this Italy falls within the best practices of such (World Health Organization, 2020; Adhikari et al., 2020).

\section{Intrinsic Socio Psycho Economic Dynamics Bothering Italian Government in this Pandemic}

The inability to produce the basics needed to support life makes life unbearable and it is an undeniable fact that many Italian regions have many deprived and vulnerable social groups that always struggle to feed and care for their immediate families and extended families that is even if all conditions are well and favorable. So in this pandemic era where there are total and partial lock downs with restriction orders on trade and industry and movement it becomes dire and extra difficult for such groups and apart from the socio economic impact, the adverse effect psychologically and emotional is heavier especially when all are home and the little money saved as emergency life fund or life insurance is been used making such people to be more weaker when exposed to life's eventualities like debilitating sudden illness, road traffic accidents, flooding, etc. There are some research works done in the UK by researchers at imperial college estimating that under the most optimistic circumstances the corona virus would kill 40,000 people in Italy and such research works should definitely be a pain to Italian political leaders and government (Fletcher et al., 1983; de Wit et al., 2016).

\section{Economic Woes of Italian Regions During this COVID-19 Pandemic}

The government of Italy has imposed restrictions on imports and exports, closed both international and local borders with neighboring and afar countries, supply and procurement chains disrupted, most industries and production companies have halted operations and definitely such shall have a serious and dire effect on general inflation and gross domestic product with Italy not exception. According to the Italian government up to 30.000 jobs in the formal and informal sectors in Italy could be lost because of COVID-19 and Italy has had high level of unemployment rate before this COVID 19 pandemic so making the case worse for the work force of Italy now.

A study released in April 2020 found that Foreign direct investment (FDI) be it tourism receipts and remittance flows will suffer significant declines as the Country tackles this pandemic. If this pandemic stays for 6 months or more then the tourism industry in Italy will suffer the worse and Calabria, Sicily, Emilia Romagna are regions that dwells much on tourism especially revenues from tourist sites, hotels etc.

In a research titled the impact of coronavirus on Italian economy conducted early April 2020 shows that if the pandemic lasts for 5 to 7 months there would be a negative growth due to disruption of the world economy through global value chains, abrupt fall in commodity prices and fiscal revenues and enforcement of travel and social restrictions.

Further to the study, Italy has also stated that a 35\% dip in exports and imports would be worth $\$ 270$ billion, yet Italy will require $\$ 80$ billion to European Union to fight against the spread of the virus and medical treatments. 
Many Italian regions have taken bold steps to salvage their people and economies but the approach by the government of Italy during this COVID-19 pandemic supersedes most and is the most action oriented. The Italian government has been taking experts advise and opinions, collaborating with the World Health Organization, the country's ministry of health, Italian health service and other agencies and has urgently designed and implemented ambitious, well informed policies to help the citizenry and the general economy with steps such stop paying bank loan for 6 months, tax exemptions for frontline health workers of COVID-19 pandemic, life insurance for frontline health workers who may be devastated by of COVID-19 in their line of service, increased pay raise and special incentive allowance for three months for some health workers starting March 2020 and if most Italian political leaders exhibit such leadership style then Italy can stand firm and tall in these hard times of the pandemic (Ministero della Salute, Dipartimento della qualità, direzione generale della programmazione sanitaria, dei livelli di assistenza e dei principi etici di sistema, 2018; Comite, 2018).

\section{How proactive are Italian political leaders and government towards science and technology}

Italian leaders were to learn effectively from the African Ebola epidemic in 2014 and were to design strong policies and set up budgets for emergencies, set up well equipped research laboratory centers for infectious diseases in many parts of country, employ more medical research scientist and create budgetary funding for such purposes. If these were done then Italy at this time would be and shall have the human resource, testing dynamics and creating of temporal immediate methods of helping deal with this pandemic. In Italy government tend to concentrate more of political goals and points than science and technology and this is the fall of Italy and the deficit it creates when natural disasters happen.

All is not lost and as Italian regions and government suffer, most may and can and should learn from this COVID- 19 pandemic and give more room for science and technology to prevail to develop Italy as a whole and more especially the regions of southern Italy which are the poorest parts of the country, infected and nearly all affected with the pandemic.

Italy per say is one of the luckiest European nations now especially in the fight of COVID-19 pandemic since the current government has formed a supplementary team to support the citizenry through public education, sharing and distributing DPI, medical consumables, cash donations, food etc to accredited facilities and deprived communities. Italy helps to deprived communities especially now and this trait is worth emulating and precedence for European and world leaders (Dawes, 2020).

\section{Global Health Dynamics and Italy Lifting its Internal Partial Lockdown}

Italy has lifted her local and internal borders of intercity, inter towns, inter suburbs for free and easy trade, access to health care, access to banks and access to pay bills etc, yet restricting churches, mosques and schools which usually are known places for close contact and crowding. Supermarkets are opened but with scrutiny for buyers and sellers to have the approved spacing interval of 2 meters. According to Owusu Nyarko et al., 2020, this is not new and can be effective to curb the continuous spread and improve the local economy when persons respect and adhere to preventive guide lines from the World Health Organization, ministry of health Italy, ministry of information Italy and the Italy health services of staying at home when outing is not urgent and of emergency, washing hands under running water with soap, applying alcohol based hand sanitizers, using face mask when going out and even in the comfort of their homes especially for those living in commercial houses and apartments and flats that share car parks, gymnasium etc. 
INTERNATIONAL JOURNAL OF ACADEMIC RESEARCH IN BUSINESS AND SOCIAL SCIENCES Vol. 10, No. 5, May, 2020, E-ISSN: 2222-6990 @ 2020 HRMARS

The research see what Italy have done by lifting the lockdown a bold and pragmatic step to open up for domestic trade and it will improve the local economy and also improve the spread of COVID -19 if Italy learn from other countries who aggressively tackled the COVID- 19 pandemic without any lock down and heavy restrictive orders on citizenry.

There are pace setter countries like Japan, Taiwan, Singapore, Hong Kong, Greece, Sweden, Switzerland, South Korea, Thailand who have still not locked down domestically due to the pandemic and Italy can learn from them. Although these are big economies and developed countries, Italy can still perfect their basics of interventions, policies and implement same to beat the COVID-19 pandemic (Changjiang Daily, 2020).

\section{The Asian giants (South Korean, Singapore, Japan, Hong Kong) style of containing the COVID-19}

South Korea as of March 25, 2020 had about over 9000 cases of COVID -19 confirmed cases which placed them among the top 10 countries for total cases but the country managed to recently to significantly slow the number of new cases without taking in strict lockdown measures and draconian orders. These countries have been able to make tactical decisions on schools, movement etc. they embarked on mass testing and tested widely for the virus, isolated cases and quarantined suspected cases and same way did Singapore also do and these two countries managed to suppress transmission of the virus. South Korea developed testing kits for the corona virus even before it had a significant number of cases.

Health authorities of South Korea conferred with research institutions to develop a test kit and after it was done it was shared to the potent pharmaceutical companies to develop and produce reagents and equipment needed for the testing. Such practice shows that testing is central to the outbreak response and without testing there will be no early detection and catastrophe can set in. Hong Kong after seeing the success of South Korea, Singapore also joined and implemented same strategies and policies to defeat the corona virus disease 19.

The approach by these Asian giants (South Korea, Hong Kong, Singapore, Japan) made the World Health Organization's director general refer to the strategy as cutting off the virus from the bud, meaning basically stopping the virus from spreading further and preventing community transmission. These countries have been able to keep most of their factories, malls and restaurants opened and Singapore has even kept schools opened at a time when nations around the world are shutting down classrooms.

There is little evidence to show that schools should be closed down in these Asian countries since the young vectors or spreaders of the COVID-19 are not evidenced based.

South Korea has used data from surveillance cameras, cell phones, and credit card transactions to map the social connections of suspected cases.

Hong Kong doesn't give out the names of those infected; health officials release each person's age, gender, street address, medical symptoms and often the exact location of where the person works. This allows other residents to determine if they might have been in contact with the infected individual. The health department of Hong Kong also releases license number plates of taxi drivers who test positive and the flight numbers of infected travelers who arrive so members of the public can determine if they might have contact. In Singapore, the police force works with the ministry of health to trace connections between cases and to track chains of transmission. Singapore also makes details of these infections' public in the hope that other residents will come forward if they may have come in contact with a confirmed case. 
INTERNATIONAL JOURNAL OF ACADEMIC RESEARCH IN BUSINESS AND SOCIAL SCIENCES Vol. 10, No. 5, May, 2020, E-ISSN: 2222-6990 @ 2020 HRMARS

1. "The aggressive efforts by the Asian giants (Hong Kong, Japan, Singapore, South Korea) to investigate and isolate every possible infection may be and could be exactly what the World Health Organization has been calling for since January 2020 but the World Health Organization may and could have failed to know that such aggressive methods is driven by financial stability and clean financial sheets and deficit free budgets from individual countries and most European countries are at the verge of diminishing returns and over ridden debt from developed countries and may not have the financial capacity to embark on such aggressive and technologically driven methods as used by the Asian giants" (Beaubien, 2020).

\section{Swedish Style of Containing COVID- 19}

In Sweden, a Nordic country during this pandemic still kept playground and schools opened, restaurant working and the government relied on voluntary action to stem the spread of COVID-19. Sweden relied much on people taking responsibility of them, protecting themselves. As of April 9, 2020 Sweden, had 9141 cases of COVID-19 virus with 793 deaths (John Hopkins University figures). The Swedish approach encouraged and recommended and never choose compulsion as done in most countries and went on the wash hands with running water and soap and stay at home awareness. Gathering of up to 50 people were still permitted, then social distancing approach, their main focus was to protect the elderly, any one older than 70 years were told to stay at home and limit any social contact (Beaubien, 2020).

\section{Taiwan Style, the Asian Country that is not a Member of World Health Organization}

Taiwan has a population of about 24 million people almost same as Australia and yet they have to april 30th 2020 less than 400 cases of COVID-19 while Australia has excess of 500 . Taiwan has been able to keep the virus under control when other parts of the world have not been able.

This is a matter of hard lessons learned during the severe acute respiratory syndrome (SARS) outbreak in the year 2003 which Taiwan was one of the most affected worldwide along with Hong Kong and southern china.

Asia has the most preventive and secured response to the corona virus by border controls, wearing of the face masks and making it as a routine in early January 2020.

Taiwan has a world class health care system with universal health coverage. As the news of COVID19 began to emerge Taiwan national health command center (NHCC) moved in to respond quickly to the potential threat (Journal of American medical Association).

Taiwan rapidly produced and implemented a list of at least 12 action items in 5 weeks to protect the public health and their policies and actions went beyond border control because to them it was not enough. Although Taiwan was at greater risk for COVID-19 due to its close proximity, ties and transport links outside mainland china.

Among the early decisions of Taiwan was to ban travel from many parts of china, stop cruise ships docking at the island ports and introduce strict punishment for anyone found breaching home quarantine orders. Further to that, Taiwan officials moved to ramp up domestic face masks production to ensure the local supply.

Taiwan rolled out island testing for coronavirus including retesting people who had previously had unexplained pneumonia, in addition, it announced punishment for those who may spread false information about the virus and COVID-19. 
A platform and made avenue for well trained and experienced teams and cadres of health care to address the emerging outbreak, however strict lock downs that characterized the response in china and many other countries were so much avoided.

Taiwan also avoided the type of "Taiwan is not a member of the World Health Organization" hence they are always planning, making policies and implementing strategies that far advances the world health care practices.

Now that Italy has opened up its domestic trade in this pandemic, it is time the government collaborates effectively, open up for expert advice, and continue to mobilize experts from the local settings and abroad to find solutions and also draw closer more to the World Health Organization.

This is the time political leaders, government in power should do all they can never and not to use excessive powers or abuse or force on citizenry even if some go contrary to regulations but rather use the time to educate such people and continuous defaulters or recalcitrant brought to book with laid down orders.

Political leaders should know that this COVID-19 pandemic is a public health crisis and all should come together to help find proper and better solutions and remedies to this course and incumbents' governments occasionally should allow itself for checks and balances since as a developing country definitely.

European countries shall borrow from the World Bank, International monetary fund, European Central Bank and others to augment their reserves to stabilize their shaking economies at this critical point of the COVID-19 pandemic. These basics of accountability and loyalty to the ordinary citizenry and the donor agencies can be done through state of nation addresses, press briefings, through a complete break down and dissemination of information to the ordinary citizen through various ministry of information or ministry of communications.

A critical observation, analysis and trend monitoring has so far shown that the Current government of Italy has been doing well and all must encourage, back and support the incumbent government's good initiative of making the ordinary citizenry and Italy know how much they are spending and the dire financial crisis this pandemic has be fallen on Italy and European countries.

Further to Italy lifting the lockdown on the domestic or internal market and economy, the country cannot stand firm only on such measure and their economy for this period shall continue to fall and dwindle since Italy's main source of income falls on export commodities which brings in foreign exchange and is a bench mark for foreign exchange liquidity that can ease balance of payment constraints and as a source of employment for the many youth. Such an intervention or initiative would help and keep the ordinary Italian and their families stable although the macro economy may suffer; it brings peace and stability within the country to avert any form of tension and aggression among the citizenry and between the governments of the day.

2. This is a good start for Italy and is a clarion call for European countries especially those in the west to emulate Italy and adapt most of the policies, interventions the current government has kept in place for the benefit of citizens and the steady tactics of fighting the COVID-19 pandemic although Italy has a long way to go and a lot to put in place to achieve the optimum (Changjiang Daily, 2020).

\section{The M3T (Mass Testing Tracing and Treatment)}

In the M3T, M stands for mass, 1st T for testing, 2nd T for tracing and last $\mathrm{T}$ for treating 


\section{Mass Testing}

Although there has been a lift on the domestic or internal lock down, there is still the higher need for mass texting especially as data made available shows levels of community spread. This will yield results since external borders with neighboring countries are closed.

In as much as the government is helping, it would be better rapid test kits that can bring results within 10 to 15 minutes are procured from world renowned laboratories and bioscience centers. Abbot and Cellex of the United States have passed through approvals from the food and drugs authority of the United States of America to bring such kits to the market and averagely cost around \$ 6 per kit (New Rutgers, 2020). Another research institute in the state university of new jersey has gained approval from the food and drugs authority of unite states on their new biomaterial collection approach called the UUCDR infinite biologics to determine SARS CoV -2 corona viruses. This is a new saliva method which will allow broader population screening than most methods used like the nose and throat swabs. Most of the testing methods are done by performing nasopharyngeal or oropharyngeal collections and usually put health care professionals at risk although they put on DPI so the new invention of saliva testing may go a long way to help.

In developing economies (like in Africa where the virus is spreading) with huge and always increasing population, it becomes a huge financial constraint for the governments due to their unstable economies yet the need to procure such fast and modern methods of testing for COVID-19 since it is over important purpose and for such a time and season. Further to that African governments need to recruit more public health and laboratory personnel to embark on such a continuous process looking at the population and it becomes another budget and unplanned cost yet vital to achieve success in the fight of COVID-19 pandemic.

\section{Tracing}

Tracing of contact persons in the population has been very relevant since there is community spread. Without such process the number of cases may go uncontrolled and the country can collapse. The social care system of Italy and most European Union are different and this makes the contact tracing very important since infected individuals unknown to them keep spreading the virus in their day to day interaction with loved ones, friends and families which they may also add up to spreading with other friends, relatives and in their line of business. This also needs human resource looking at how varied such practice is and calls for another unbudgeted cost by the government.

\section{Treatment}

Treatment now becomes key when persons infected are identified. This can only be done in accredited centers for such purpose. The fewer the cases the better for our treatment centers and the efficient management of infected persons by the health care professionals. If the number of cases goes higher than the need for more accredited centers to be established and more health care professionals recruited with expanding need for medical consumables and this becomes another headache for Italian government since is a financial burden and an unplanned budget.

\section{The 2SQ (Social Distancing, Self -Isolation, Quarantine)}

In the $2 \mathrm{SQ}$, the $2 \mathrm{~S}$ stand for social distancing and self-isolation while the $Q$ stands for quarantine. 


\section{Social Distancing}

Social distancing purposely is to decrease the transmission risk. It usually stats with bigger groups of people like churches, mosques, schools, football games. In fact, it becomes necessary when one avoids all non-essential activities. One must avoid contact with persons and maintain a 2 meters part distance to any time when nearing people. The very point of social distancing is to prevent those numbers from going up and actually to flatten the curve of infections over time. Nonetheless since the COVID-19 is an airborne disease and despite the social distancing it will still infect people.

\section{Self-Isolation}

Self-isolation is basically for people who have come into contacted with infected persons or someone who has lived in or returned from a country with more cases of COVID-19.such individual usually don't show symptoms but is a kind of precautionary measure and they should avoid staying out of home, limit physical contact with others and avoid petty transits. They should then be educated on the symptoms and they monitor themselves for respiratory symptom so sneezing, coughing, fever and shortness of breath.

\section{Quarantine}

This comes into operation when persons have been tested for COVID-19 and waiting results or have tested positive for COVID-19. Such persons are usually confined to accredited centers or kept home in a prepared place and all is done to prevent them from getting into contact with others as much as possible (Gupta, 2020; Zeni, 2020; Fletcher et al., 1983; Darwish, Ahmed, \& Pahi, 2020).

\section{Conclusions}

In as much as the COVID-19 is fatal and a global health crisis, there should be an opportunity for Italy and European government to take bolder, more pragmatic steps to secure and shield supply chains of essential products, strive hard to contain the health crisis, strive hard to maintain the stability of their financial systems, help businesses survive the crisis, support households economic welfare and there should be a way to compensate stimulus package to reverse the economic damage the crisis is still causing.

Research shows how fast action in the face of the COVID-19 problem can avoid even more critical situations.

In fact, the probability of a person affected by the virus and hospitalized worse depends on the quality of the care provided.

The model of care must be multidisciplinary.

we can say that we are writing a book of which we currently only know the title (COVID-19).

In fact, the disease can leave consequences that require monitoring over time.

The reconstruction of the sanitary and economic rubble cannot ignore the psychic wounds, without which the social fabric will be very weakened, with an avoidable risk of increasing poverty.

\section{Recommendations}

As Italy e many European countries always have ailing economies, the International monetary fund, World Bank and European Central Bank should try as matter of relief to give long span loans without interest to affected European countries with this COVID-19 pandemic looking at its devastating effect on the economy. 
The developed world as been affected by the pandemic shall definitely be stable and recover from any economic decline COVID 19 has befallen on them and should try and consider waiving off sovereign debts of severally hit European countries with the COVID 19 pandemic since at this time debt relief is indispensable especially when imports and exports are hard hit with severe restrictions in most European countries.

The research advises the extremely important need for social distancing, self isolation, quarantine and may be international boundary lock down when the need be. Also, it is inevitable at this stage to forget mass testing, tracing and treatment which is a major tool and approach which has been effective and result oriented public health intervention and that border closures or international boundary lock with the public health intervention of mass testing, tracing and treating becomes a zero and defective effort.

Some of the italian leading epidemiologist, infectious disease specialists, think is time European countries do as much as they can to emulate the aggressive approach the Asian giants (Singapore, South Korea, Japan, Hong Kong, Taiwan) took through with their health care system and also the process, policies, strategies and implementation done to conquer COVID-19 as against the rest of the world.

In summary you will need:

- increase the qualitative and quantitative level of the health service;

- develop a database that includes all those who have contracted the virus;

- gradually resume economic activities to revive the economy;

- create a virtual network of collaborative medicine that becomes a model of cure for the future.

\section{References}

Adhikari, S. P., Meng, S., Wu, Y. J., Mao, Y. P., Ye, R. X., Wang, Q. Z., Sun, C., Sylvia, S., Rozelle, S., Raat, H., and Zhou, H. (2020). Epidemiology, causes, clinical manifestation and diagnosis, prevention and control of coronavirus disease (COVID-19) during the early outbreak period: a scoping review. Infectious diseases of poverty, 9 (1), pp.1-12.

Beaubien, J. (2020). How south Korea reined in the outbreak without shutting everything down as published in NPR : www. Npr.org March 26, 2020, 2:41 PM ET

Boateng, O. N., Weyori B. A., and Tetteh L. A. (2020). Optimized Authentication Model for Online Transaction Payments, Journal of Computer Science

Changjiang Daily (2020). Wuhan City, new coronavirus infected pneumonia prevention and control headquarters notice (no. 1). Available online:

http://www.wuhan.gov.cn/2019_web/whyw/202001/t20200123_304072.html

Comite, U. (2011). Healthcare Autorities: between functional integration and clinical governance. The economic - business aspect and managerial determinants of clinical practice, published in EBES program and abstract book 2011 ISBN 978-605-61069-3-4, Conference-Zagreb, October 13, 14, 15, 2011.

Darwish, S., Ahmed, U., \& Pahi, M. H. (2020). Innovative Work Behavior During COVID-19 for Medical Representative in the Pharmaceutical Industry: Test of a Moderation Model in Bahrain. International Journal of Pharmaceutical Research. 12(4), 1927-

1934. doi.org/10.31838/ijpr/2020.12.04.277

Dawes, D. E. (2020). The Political Determinants of Health. Johns Hopkins University Press. 
INTERNATIONAL JOURNAL OF ACADEMIC RESEARCH IN BUSINESS AND SOCIAL SCIENCES

Vol. 10, No. 5, May, 2020, E-ISSN: 2222-6990 @ 2020 HRMARS

De Wit, E., Van Doremalen, N., Falzarano, D., and Munster, V. J. (2016). SARS and MERS: recent insights into emerging coronaviruses. Nature Reviews Microbiology, 14 (8), p.523.

Essentials of Health Behavior (Essential Public Health). (2019). 2nd Edition by Mark Edberg

Fletcher, R. H., and Fletcher, S. W. (1983). Clinical epidemiology: a new discipline for an old art. Annals of internal medicine, 99 (3), pp.401-403.

Gordis, L. (2017). Epidemiology. 4th Edition, Saunders.

Gupta, S. (2020). Corona virus, distancing, isolation, quarantine, lock down: what's the difference; published on March 17, 2020 in tvo: www.tvo.org

Lister T., Shukla S. (2020). Sweden challenges trump and scientific main stream by refusing lock down $\backslash$; published in world CNN on April 2020 9:33 GMT

Ministero della Salute. (2018). Dipartimento della qualità, direzione generale della programmazione sanitaria, dei livelli di assistenza e dei principi etici di sistema, Ufficio III, Sicurezza dei pazienti e gestione del rischio clinico: manuale per la formazione degli operatori sanitari, Roma

New Rutgers saliva test for corona virus gets FDA Approval published in Rutgers today news outlet on April13, 2020, www.rutgers.edu

World Health Organization. (2020). Coronavirus disease 2019 (COVID-19): situation report, 70.

Zeni, M. B. (2019) principles of epidemiology for advanced nursing practice: A principle health perspective 1st edition ISBN - 13: 978 - 1284154948 